\title{
The Students' Religion Attitude: Study of Pesantren Ramadhan for Senior High School in Padang City
}

\author{
Hasan Zaini1, Nofri Andy. N2*, Hilma Pami Putri \\ ${ }^{1}$ Institut Agama Islam Negeri Batusangkar, Indonesia \\ 2Institut Agama Islam Negeri Bukittinggi, Indonesia
}

Corresponding Author: Nofry Andy. N, @ nofriandy.n@gmail.com*

$$
\text { ABSTRACT }
$$

The Padang City Government creates Pesantren Ramadhan activities as a media for fostering faith and devotion in forming character society. This article aims to analyze the role of students' religious attitudes after

ARTICLE INFO

Article history:

Received

January 29, 2020

Revised

May 22, 2020

Accepted

June 07, 2020 participating in Pesantren Ramadhan by analyzing applied learning patterns. This study used a descriptive analytical approach. The data derived from interviews and observations. The results of this study showed that: (1) Pesantren Ramadhan has been carried out for 12 times activities and has an impact on the way students behave in daily life and the application of religious practices is applied in a sustainable manner (2) Knowledge, belief, and understanding of religion become stimulation in increasing religious attitudes (3) The Padang City Government makes Pesantren Ramadhan as a media in forming the character of the young generation in order to have a noble character.

Keywords: Students' Religion Attitude, Pesantren Ramadhan, Learning Pattern

How to Cite Zaini, H., Andi, N., \& Putri, H. (2020). The Students' Religion Attitude: Study of Pesantren Ramadhan for Senior High School in Padang City. Jurnal Iqra' : Kajian Ilmu Pendidikan, 5(1). 120-132. https://doi.org/10.25217/ji.v5i1.743

Journal Homepage http://journal.iaimnumetrolampung.ac.id/index.php/ji/

This is an open access article under the CC BY SA license

https://creativecommons.org/licenses/by-sa/4.0/

Published by Institut Agama Islam Ma'arif NU (IAIMNU) Metro Lampung

\section{INTRODUCTION}

The Pesantren Ramadhan activity is an alternative activity for extracurricular activities in order to strengthen the formation of faith and devotion to Allah SWT for muslim of students with the pattern and procedures of pesantren life which is conducted in schools during Ramadhan. It is consistent with the views of experts revealing that the system of learning in pesantren is considered successful because of the tendency of parents in big cities is no longer and be able to control and direct their children from juvenile delinquency (Syafe'i, 2017; Ma'arif, S. 2018; Nurjan, S., Tjahjono, H. K., \& Yamin, M. N, 2019). Lack of time for religious studies in public schools makes the materials delivered to the students is not optimal and efforts to build good character are not achieved. It makes degradation of morals among students (Nuqul, F. L., \& Ningrum, A. R. M, 2020; Muthohar, 2016). Hence, an effort to minimize juvenile delinquency and improve student diversity in the City of Padang, the Government of the City of Padang issued Instruction No. Mayor of 
Padang 451.3022 / BINSOS-IX / 2004 dated September 6 regarding the activities of the Islamic Boarding School Ramadhan (Tolib, 2015).

The spirit of the program was taken from the pesantren system in Indonesia, but was modified with short time and materials. In education of Indonesia, the pesantren learning system is considered successful because the tendency of parents in big cities is no longer able to control and direct their children from juvenile delinquency. One of the solutions is to effort their children to boarding school in order to get empowerment. The tendency of children towards pornography, drugs, and the development of radical understandings has made the Government handling this matter seriously. It was by galvanizing for students in transferring learning and teaching activities from school to the mosque

The forerunner of the Pesantren Ramadhan is a flash boarding school activity which is held for three days in schools to replace the student holidays and at the same time deepening religious knowledge. As a result the students' understanding of religious valuesis stronger and can apply those values in daily life. This activity has a positive effect, especially in realizing the vision and mission of the Padang city, the religious city to fulfill the objectives of national education, including increasing the faith and piety in an effort to form person and the entire Indonesian community as a whole.

As a city that has a vision of creating a religious city of Padang, this activity aims to explore religious knowledge and be able to apply these values in everyday life. Another equal important aspect is the fulfillment of national education goals, which is to form complete human being. For these long, the role of parents is always replaced by teachers at schools. Meanwhile, the formation of character starts from the family (home). Many families find disorientation is not only because of the economic crisis but also because of the current globalization of values and lifestyles which are not in accordance with national and local religious, socio-cultural and cultural norms. These are like the hedonistic lifestyle, matrealistic and permissive contained in telenovela and soap operas on various TV sets in Indonesia. It is causing the family disorientation and dislocation (Effendi, 2018).

Numerous previous studies related to the discuss Pesantren Ramadhan. The first conducted by Jumain, about the effectiveness of Pesantren Kilat on self-regulation ability in terms of emotional intelligence and social maturity in adolescents explained that the experimental group that was given training in Pesantren Ramadhan showed an increase number in intelligence by $34.3 \%$ and social maturity by $42.3 \%$ (Jumain, 2015). Besides, Marpuah analyzed the instructional design for the moral development students in Pesantren Ramadhan. The childhood was low development so that they are unable to use and apply the principles of right and wrong. Their tendency to follow regulations that are not in accordance with the benefits of the rules. The finding shows that behavioral technique through giving a good example has provided a significant changing on the students' moral behavior (Marpuah, 2014). Then research's Marpuah who reported that the implementation of extracurricular 
religion study: spiritual activities in State Senior High School (SMAN) 1 Cirebon city. His article discussed about the ineffective learning of religion in the classroom, the students only focused on fulfilling cognitive aspects (Marpuah, 2016). The last was the recent research conducted by Endin Mujahidin in 2017 who interested in the development of model Pesantren Kilat in Innovative and the Effective model. As a result, the effective pesantren kilat model exist if the relation within teacher and students, for instance like as kyai and santri (Mujahidin, 2017).

Previous studies above gave a contribution to the students in learning process. Unfortunately, those did not integrate with religious attitudes after participating in Pesantren Ramadhan by analyzing applied learning patterns. From those previous researches, there are some criticisms toward the implementation of Pesantren Ramadhan or better known as the pesantren kilat, caused by the students inability to get the material on the implementation stage. In this research, the researchers examined the implementation of Pesantren Ramadan undertaken by high school students who have repeatedly held and analyse the impact to the students' religion sustainability. This article became interesting and get support of the Padang City Government by issuing the legality arrangements in this program. This article got stronger and unimpressive to fill the student holidays in the month of Ramadan.

\section{METHODS}

It was a qualitative descriptive research. It is a method that describes the object analyzed or samples that have been collected, then making conclusions (O’Dwyer \& Bernauer, 2013; Loeb et al., 2017). In other words, the descriptiveanalytical method focuses on the problems found in the field of study (Moser \& Korstjens, 2018). This research was conducted in Padang city, precisely at State of Senior High School (SMAN) 1 Padang, (SMAN) 3 Padang and Al-Azhar Air Tawar Padang Mosque and Al-Furqon Muaro Mosque of Padang City. The sample was taken from 60 students of the twelfth grade that come from those four research locations.

Data collection in this study used interview and observation. The observations and interview were done to the activities in the twelfth grade students in participating Pesantren Ramadhan and seven teachers. The interview is related to students' views regarding the Pesantren Ramadhan. The data collection techniques used purposeful sampling techniques in determining the source of the research data. Furthermore, the process of data collection emphasizes the use of qualitative interview procedures, researchers conducting face-to-face interviews with the participants who have determined as a sample of the research data. The participants was seven teachers in SMA N 1, SMAN 3, Al Azhar Air Tawar Padang Mosque, and Al Furqon Muaro Mosque. The teachers also explained learning material provided as well as the strategies used and the evaluation related to the implementation of Pesantren Ramadhan. These interviews and observations become important in answering the research questions related to increasing student' religiosity. 
While the analysis method and interpretation of the data which was used by researchers refer to the steps of analysis raised by Creswell (2016), First, Processing and preparing data for review; Second, reading the entire data; Third, Starting to code all research data; Fourth, describing the category and the theme settings to be analyzed; Fifth, Presenting qualitative narrative reports, and Sixth, Making interpretations in qualitative research

\section{RESULT AND DISCUSSION}

\section{Religious Attitudes and Influencing Aspects}

There are two significant in religion, namely doctrine and religiosity. Doctrine is a sacred oral or written text and is a reference for followers of religion. Whereas religious (religiosity) is a behavior that comes directly or indirectly to religion (Fridayanti, 2015). These two things should ideally be in line and the text used as the reference source is the initial guideline in carrying out the norms they contain. In the present context, a lot of people's religious feelings are more than what they know from religious texts, so this behavior will have an impact on how they interact socially with others, as well as the emergence of radical understanding of religion is a cause of high religious diversity but not accompanied by knowledge about the doctrine of religion itself.

The religion behavior is an attitude of one's obedience to the religion. This word comes from English "religion" means, obedience, worship and faith. This term is different when coupled with the word religion (ad-din). Someone's religion is determined by how far the knowledge, beliefs, implementation of the worship, and the appreciation of the religion they embrace. For a Muslim, this can be seen from how far the knowledge, beliefs, implementation and appreciation of the Islamic religion (Awang, Hambali \& Khadijah, 2017). This attitude will arise in a person after the gathering of religious knowledge, religious feeling and religious behavior.

In religious practice, a person must have an orientation, All port and Aryani (2016) explain a person's religious orientation is divided into two things, including: extrinsic and intrinsic. The extrinsic orientation believes that religion is something that is utilized and not carried out in life. This orientation uses religion only as a need for status, security, and self-esteem. The people who are having this religious act, will carry out the forms outside of religion, such as fasting, prayer, Hajj, etc. but not in it. Meanwhile, the intrinsic refers to the acceptance of religion in the individual as the main motive and need. The individuals who have a high intrinsic religious orientation can build a balanced life between beliefs and religious behavior (Francis, Jewell \& Robbins, 2010).

The lack of effective religious education as described above can raise concerns about the nation's mentality in the future. Then the activity of Pesantren Ramadhan is the best alternative for strengthening religious values. for students as a substitute for the lack of religious instruction in schools along with clear management for those responsible for this matter. Pesantren Ramadhan is an education that is carried out with a system of Islamic boarding 
schools, only the implementation is carried out in a short time. There are five advantages to the learning patterns applied in the pesantren and this is adopted by the Pesantren Ramadhan, they are: Islamic boarding schools prioritize the practice, such as practice in prayer, fasting, and so on. In addition, the characters are highly respected in everyday life. The education system in boarding schools is very effective to be applied in mentoring and guiding students mentality, because for 24 hours it is under the supervision of clerics The learning hours are more, because they are organized (Indah, 2019). The children in boarding schools are far from negative influences from outside, because they are bound and protected by existing regulations. In boarding schools, the children are trained to live independently, to be in a community, and to work with others Basically the Pesantren Ramadhan activities aim to improve students' understanding, appreciation, and practice of the teachings of Islam, so that they become believers and devote to Allah as well as having good moral in their personal lives, community, nation and state.

\section{The Dynamics of Pesantren Ramadhan in Padang City}

Pesantren Ramadhan starting from elementary school students from the fourth grader up to the sixth grader, from junior high school as well as senior high school and the vocational school have been carried out since 2004. In the process of implementation, evaluation, improvement and stabilization have been carried out both in terms of curriculum, procedures for implementation, valuation or financing. In 2015, the focus was on strengthening short verses and Asmaul Husna. The Pesantren Ramadhan was equipped with teaching materials and lesson plans for each levels.

Padang City is a pilot project for West Sumatra in the implementation of the Ramadhan Islamic boarding school. This activity lasted for two weeks (1228 June 2019) which was held in mosques. But in the past two years, this activity was also carried out in schools, such as SMAN 1 Padang, SMAN 3 Padang, Al-Azhar Air Tawar Padang Mosque and Al-Furqon Muaro Mosque of Padang City. Basically, the Pesantren Ramadhan is a learning process that is transferred from school to mosque and prayer room, because there are several benefits, including students being taught directly to love mosques by enlarging the mosque and most importantly training mentally when mingling with other students (Budi, 2019). Another benefit of implementing this activity in schools is the implementation, management and targets achieved better than the implementation carried out in mosques and prayer rooms. The implementation of activities at school has a rather high weight because it is supported by facilities that are sufficient for teaching learning process of Pesantren Ramadhan, the maximum teacher involvement and supervision of the Principal. According to Yerni (2019) the implementation of Pesantren Ramadhan in mosques has many benefits, including establishing friendship among students who come from various schools and fostering disciplinary attitudes such as santri required to pray in congregation. Then, when this activity was carried out in schools, researchers saw something interesting like 
the togetherness of all teachers in the encouraging the success of this activity. This can be felt when the Headmaster goes down and immediately watches at the school gate to watch the students who arrive late and they are given punishment in the form of memorizing the five verses of the new Qur'an and then being allowed to take part in ongoing activity (Nukman, 2019).

\section{Learning Methods in Pesantren Ramadhan}

The result interview of using learning methods in Pesantren Ramadhan involve: "the method in learning of Pesantren Ramadhan in 2019 was very different from the previous pesantren method. Where then there are more in the classical form or lectures by experts or called Buya or lecturers. The teacher uses personal and small group approaches or methods and other learning methods that cannot be ignored, such as the method of obedience and habituation.

Moral development pursued by Islam is using integrated methods or systems, namely systems that use various religious and other facilities simultaneously to be directed towards moral formation. Another way to go in moral development is: coaching, exemplary, getting along with good people, affective guidance can be done by paying attention to psychological factors. The learning methods of Pesantren Ramadhan include: The first exemplary methods (uswah). It is psychologically humans really need an example to develop their characteristics and potential. Education through exemplary is education by giving concrete examples to students. For example, a teacher and mentor always give good deeds to the santri, in ritual worship, daily life and others. Exemplary shown can be through words, actions and clothes. The second was exercise methods and habituation. It is usually this method is applied in amaliyah worship, such as congregation prayers, courtesy of association with fellow friends and the like. The method of training and culture is the main activity in the implementation of the Pesantren Ramadhan in Padang city. The third was the Ibrah method (taking lessons), according to Abdurrahman AlNawawi as quoted by Tamyiz defines ibrah with a psychological condition that conveys humans to know the essence of a matter that is witnessed, observed, indented, weighed, measured and decided reasoning so that the conclusion can influence the heart to submit to him, then encourage it to appropriate social thinking behavior. The fourth was the Mau'idzah (advice) method. Zamani \& Al Baqi (2019) interpreted mau'idzah as follows: mauidzah is a warning advice on kindness and truth in whatever way can touch the heart and raise it to initiate it. The mauidzah method must contain three elements, first a description of the improvement and truth that the santri must do, secondly there is motivation, the third statement about sin. The fifth was discipline method. It is a directed, organized a child who has been accustomed is always disciplined later in his daily life will become more directed. The discipline applied in lightning schools in this school is time discipline, in the time discipline here students are trained to always respect time. For example, respecting time in learning, here students are required to always be on time, that is, students are already in the class and 
start time to always tadarusan (read holy qur'an) together before teaching and learning activities begin, discipline in giving opinions, discipline to pray on time, and others -other. The sixth method of Targhib wa at-Tarhib. It is the scientific understanding found by Abdurrahman Al-Nawawi targhib is a promise accompanied by persuasion and seduction to delay the benefit, delicacy and pleasure, however, the delay is certainly good and pure, and carried out through the beginning of school or prevention of harmful delights (bad work), this is done to seek the pleasure of Allah and that is a blessing from Allah. Whereas tarkib is, a threat or intimidation through punishment caused by the implementation of a sin, mistake or act that has been forbidden by God.

From the six learning methods above, it can be concluded that the method of example is a fairly effective method in fostering religious attitudes in students, because in the exemplary method students are always guided and nurtured based on the reality and experience gained in the activities of the Pesantren Ramdahan.

\section{Implementation of Pesantren Ramdahan in Mosques}

The reason for making the mosque as a place of activity is to support the government's program to return to surau. The progress of the times caused children to be reluctant to the mosque so that the mosque became quiet and resulted in this generation not getting enough spiritual water, this was very much in contrast when compared to the ancient times where so many people gave benefits in shaping the personality of the nation's children.

The Pesantren Ramadhan activities held in the mosque in the city of Padang are planned activities in accordance with the appeal of the Padang City Government. Participants in the Ramadan Islamic boarding school are students who are in the local mosque (Nukman, 2019). The researchers met at the Alazhar Air Tawar Padang mosque and the Al-Furqon Muaro Penyalinan Padang mosque. As long as researchers conduct observations and interviews in the field, they encounter a diversity of students ranging from elementary, junior high, and senior high school education units to the same degree.

The activity of learning Pesantren Ramdahan at the Al-azhar Air Tawar Padang mosque is not much different from the implementation of Islamic boarding schools in schools. But the difference is that the mentors in the AlAzhar and Al-Furqon mosques are independent. The learning method in the implementation of Pesantren Ramdahan in the al-Azhar and al-Furqon mosques consists of two strategies, namely the lecture and group methods (Nukman, 2019; Mahyeldi, 2019). The lecture method is carried out by hearing from the community leaders or scholars who have been compiled by the committee. The group method is also carried out by mentors and mentors and school teachers. Can researchers describe in more detail the methods of implementing the Pesantren Ramdahan is as follows:

Based on the observations of researchers in the field of methods of moral education in the Pesantren Ramdahan is almost the same as the method of moral education applied in Islamic boarding school education. Because 
participants must take part in the activities and be supervised by the committee. The gathering of several children in an activity can foster a sense of solidarity and can share knowledge among their fellow human beings.

\section{Pesantren Ramadhan Learning Material}

In 2019, the focus of Pesantren Ramadhan was to maximize the quality of faith and religious knowledge which would have a positive impact, namely the practice of values in Islam in accordance with the guidance of the Qur'an and Hadith. While in the distribution of schedules there are three shifts, namely the morning prayer in congregation followed by all participants. Then proceed with the first shift for the high school level from 06.00-09.30 WIB, 10.00-12.00 WIB is the time for the elementary level, and the last from 13.00-15.30 WIB for the junior high level.

The material in Pesantren Ramadhan 2019 boarding school activities especially in schools is more varied according to the level of student development. After the discussion was held the discussion focused more on group needs such as LGBT, femininity, and current issues. Through interviews with mentors about Pesantren Ramadhan material, the mentor answered "the Islamic boarding school Ramadhan material has outlines from the guides that we got during the mentoring or debriefing of the mentor. Current material such as LBGT that is being warmed up is often asked by students. The same question also led the leader's mentor "what is the emphasis of the material on the boarding school this year?" The head of the mentor answered "besides the subject matter of fasting, prayer, morality and charity, students are more interested in discussing moral material related to disgraceful character or LGBT. "Student questions also revolve around their individual needs and experiences." The researchers can conclude that the smaller the group that is formed, the more it gives the opportunity for students to explore the religious material in improving the religion of students through the Pesantren Ramadhan.

\section{Religious improvement Students through the Pesantren Ramadhan}

Pesantren Ramadhan in its implementation is expected to improve students' religion. The month of Ramadhan is a month of wisdom and the meaning for it is carried out by the students of Ramadhan both at school and in the mosque. Through Pesantren Ramadhan, the students discuss various religious material such as fasting, prayer, zakat and morality. Other material such as phenomena and issues that develop in the Islamic world and the phenomena in their environment and what they see and witness in eloctronic media are interesting discussions in the discussion.

In the morning around 8:30 a.m., the researchers arrived at the school yard of SMAN 3 Padang to conduct research data collection. The researchers saw many students sitting in groups on the terrace of the mushalla while reading the Qur'an there was also a group of others who were doing dhuha prayers. Not satisfied with seeing while taking photographs, researchers also joined sitting with one group of female students reading al -Qur'an and friends read 
their meanings. The morning discussion revolved around women and their ins and outs in Annisa's surah.

The researchers asked the head of one of the students' questions. "Through the activities of the Pesantren Ramadhan, what are the things that you feel in improving religion?

Informant 1 or female students answered: "Through this Pesantren Ramadhan there are many things that make me interested and at home and improve my faith including: in the morning we arrive at school we do tadarus, and pray dhuha, then discussions with issues that are warm like LBGT. Finish tadarus we pray circumcision Dhuha, to pray circumcision Dhuha we are directed and invited coolly, for those who do not feel loss themselves ".

Furthermore, the researchers met with other groups who had just finished performing the dhuha circumcision prayer with the same question "What are the things about the ramadhan pesantren that you feel in improving religion?

Informant 2 replied: "Through the Pesantren Ramadhan in the holy month, there were many things that I felt in increasing my faith including: morning until at school many friends had read the Qur'an so I was also motivated to read it, secondly we were encouraged to pray the circumcision of Dhuha without coercion. After that we discussed Islam, doing good things and coming to charity during the fasting month.

After conducting several interviews with students in four locations, researchers found several paradigms regarding increasing diversity after attending the Pesantren Ramadhan. Pratiwi (2019) the third class student at Senior High School (SMA) 1 explained that this activity was very positive for us in studying religion, many things that were gained from this activity included memorizing the asthma of the Prophet, short verses, fasting Thursday and several other things. which is very supportive in learning. Indeed, I have taken part in this activity since I was in junior high school. It was rather bored, but there were some of the most important things, among others, that I could gather again with close friends who rarely met and could love the mosque as the house of God.

Dudung, D. (2007) stated that as a positive proof of the 12 activities this time, there were raids on community diseases both at lauik, karaoke, cafes, and so on, none of them were Pesantren Ramadhan alumni either male or women. Those found in the raid came from various regions in West Sumatra.

The implementation of the Pesantren Ramadhan every year should be evaluated and must be supported by all existing elements, there is no dichotomy between general and religious lessons. Religious studies are very important to make the child have more adab and good ethics. The increase in diversity has an influence on student achievement. We can pay attention to students who are diligent in fasting Monday and Thursday, Dhuha prayer, midnight prayer in congregation and other religious activities there are people who have high discipline and are very appreciative of time so that no time is wasted for them. Therefore, when Ramadhan arrived they were happy to welcome him (Yerni, 2019; Indah, 2019). Another great benefit of their 
Ramadhan activities is visited by figures from Padang City who are ready to share their experiences in achieving success.

After observing several times to the location, the researchers looked at how the school environment was very influential in the religious life of students, especially for schools that were sampled as favorite schools in Padang City and their students were excellent students. Researchers pay attention to how they when the Dhuha performed the Dhuha prayer then recited for a while, then when the Zuhr prayer they prayed in congregation and there were no 650 students absent except those who were unable to attend, then held a cult and lecture, after the ashar they also prayed in greetings but there were also some who made a memorization. The things described above are only the parts that are zahir (visible) only, but those that are personal are also many such as fasting, memorizing verses and so on also often they do.

The findings of this study was Increasing the students' religiosity after participating in Pesantren Ramadhan in Padang city. The XII grade students who have participated in pesantren have experienced a significant increase in religiosity after participating in the that activity. It was because they have done this activity every year, starting from elementary school level. It can be seen from the consistency in implementation the values Pesantren Ramadhan not only in Ramadhan, such as Thursday's fasting, Duha prayer, and tahfiz alQur'an. This research different from the four previous researches (Mujahidin, 2017; Marpuah, 2016; Jumain, 2015; Marpuah, 2014) who tend to view the Pesantren kilat or Pesantren Ramadhan as holiday fillers and have not had a direct impact on students. On West Sumatra context, Padang City with Pesantren Ramadhan activities is as a means of forming student character becomes a reference for other districts or cities and even outside West Sumatra region to adopt this activity both in terms of material and its implementation. Because learning intensive in pesantren be able to control and avoided their children from juvenile delinquency (Ma'arif, S. 2018; Nurjan, S., Tjahjono, H. K., \& Yamin, M. N, 2019).

\section{CONCLUSIONS}

The Pesantren Ramadhan activities that have been held twelve times provide positive meaning for high school students in the city of Padang, including increasing the diversity of students' attitude seen from the musty worship that they do daily such as the continuous dhuha prayer, fasting on monday and thursday, motivation memorizing the Qur'an and various other religious activities. Pesantren Ramadhan activities are supported by several parties who are competent in their fields, such as speakers, mentors, supervisors, and so on. While the method applied is exemplary method, training method and habituation, ibrah method (taking lessons), mauidzah method (advice), disciplinary method and Targhib wa tarhib method. After the Pesantren Ramadhan was over, researchers made observations several times in Senior High Schools 1 and 3 in Padang City and the researchers still found students diligently carrying out Dhuha activities, reading the Qur'an, Seven 
Minutes Lecture and several other religious activities and after the researchers asked some of their students to answer the Islamic boarding school activities, there were many impressions and lessons learned.

\section{ACKNOWLEDGEMENTS}

The researchers would like to thank Al Amin as Head of Public Welfare in Padang City for assisting researchers in completing the data. Thank you also delivered to Drs. Nukman, M.Si as the principal of State of Senior High School (SMAN) 1 Padang and Drs. Ramadhansyah, M. Pd as Principal of SMAN 3 Padang who has given permission to carry out research in schools. Thanks also to Rimelfi, S. PdI, MA, who link the researchers and students, religion teachers and trainers to collect research data.

\section{AUTHOR CONTRIBUTION STATEMENTS}

This article was a collaborative research of two universities. In research $\mathrm{HZ}$ and NA jointly design the research, collect the data, analyze the data and conduct dissemination together. Then, HPP is the third author as a researcher who helped to complete as well as finishing this research.

\section{REFERENCES}

Aryani, S. A. (2016). Orientasi, Sikap Dan Perilaku Keagamaan (Studi Kasus Mahasiswa Salah Satu Perguruan Tinggi Negeri di DIY). Religi: Jurnal Studi Agama-agama, 11(1), 59-80. https:// doi.org/10.14421/rejusta.2015.1101-04.

Awang, A., \& Mohd hambali, k. (2017). Apresiasi Dialog Kehidupan Berhikmah Komuniti Cina Muslim di Terengganu. Kemanusiaan: The Asian Journal of Humanities, 24(1). Google Scholar

Brewer, G., Robinson, S., Sumra, A., Tatsi, E., \& Gire, N. (2015). The influence of religious coping and religious social support on health behaviour, health status and health attitudes in a British Christian sample. Journal of religion and health, 54(6), 2225-2234.. https:/ / doi.org/10.1007/s10943-014-9966-4.

Budi. (2019, 12 June). The Result Interview, Teacher at SMAN 1 Padang, at Padang City.

Creswell, J. W. (2014). Penelitian Kualitatif dan Desain Riset, Memilih diantara Lima Pendekatan. Yogyakarta: Pustaka Pelajar. Google Sholar.

Creswell, J. W. (2016). Research design: pendekatan metode kualitatif, kuantitatif, dan campuran. Yogyakarta: Pustaka Pelajar. Google Scholar.

Dudung, D. (2007). Pendidikan Agama: Urgensi dan Tantangan dalam Ilmu dan Aplikasi Pendidikan. Jakarta: Imtima. Google Scholar

Effendi, Y. (2018). Revitalisasi Peran Sosial Surau Dagang Dalam Pembentukkan Karakter Masyarakat Pasar Tradisional Di Padang Pariaman. Islam Realitas: Journal of Islamic \& Social Studies, 4(1), 48-56. http:/ / dx.doi.org/10.30983/islam_realitas.v4i1.508.

Francis, L. J., Jewell, A., \& Robbins, M. (2010). The relationship between religious orientation, personality, and purpose in life among an older 
The Students' Religion Attitude: Study of Pesantren Ramadhan for Senior High School Students in Padang City

Methodist sample. Mental Health, Religion $\mathcal{E}$ Culture, 13(7-8), 777-791. https:/ / doi.org/10.1080/13674670802360907

Fridayanti, F. (2015). Religiusitas, Spiritualitas Dalam Kajian Psikologi dan Urgensi Perumusan Religiusitas Islam. Psympathic: Jurnal Ilmiah Psikologi, 2(2), 199-208. https:/ / doi.org/10.15575/psy.v2i2.460.

Indah. (2019, 25 June). The Result Interview, Teacher Al-Furqon Muaro Mosque of Padang City, at Padang City.

Jumain, J. (2015). Model Pendidikan Di Pesantren Rakyat Al-Amin Sumberpucung Malang. J-PAI: Jurnal Pendidikan Agama Islam, 1(2). http:/ / dx.doi.org/10.18860/jpai.v1i2.3351.

Loeb, S., Dynarski, S., McFarland, D., Morris, P., Reardon, S., \& Reber, S. (2017). Descriptive Analysis in Education: A Guide for Researchers. NCEE 20174023. National Center for Education Evaluation and Regional Assistance. Google Scholar

Ma'arif, S. (2018). Education as a Foundation of Humanity: Learning from the Pedagogy of Pesantren in Indonesia. Journal of Social Studies Education Research, 9(2), 104-123. Google Scholar

Mahyeldi. (2019, 26 June). The Result Interview, Teacher Al-Furqon Muaro Mosque of Padang City, at Padang City.

Marpuah, M. (2014). Manajemen Konflik Keagamaan: Kearifan Lokal Dalam Upaya Resolusi Konflik Keagamaan di Sumatera Barat. Turast: Jurnal Penelitian dan Pengabdian, 2(1), 35-52. Google Scholar

Marpuah. (2016). implementation of extracurricular religion study: spiritual activities in sman kota cirebon. Al-Qalam, 22(1) https:// doi.org/10.31969/alq.v22i1.300.

Moser, A., \& Korstjens, I. (2018). Series: Practical guidance to qualitative research. Part 3: Sampling, data collection and analysis. European Journal of General Practice, 24(1), 9-18. https:/ / doi.org/10.1080/13814788.2017.1375091

Mujahidin, E. (2017). Pengembangan Nilai-Nilai Spiritual Berbasis Pesantren Kilat (Studi Pengembangan Model Pembelajaran Pesantren Kilat yang Inovatif dan Efektif untuk Siswa Sekolah Lanjutan Tingkat Atas). Edukasi Islami: Jurnal Pendidikan Islam, 1(02). http:/ / dx.doi.org/10.30868/ei.v1i02.25.

Muthohar, S. (2016). Antisipasi degradasi moral di era global. Nadwa, 7(2), 321334. http:/ / dx.doi.org/10.21580/nw.2013.7.2.565

Nuqul, F. L., \& Ningrum, A. R. M. (2020, February). Considering the Potential of Pesantren's Constribution in Diversion Programs for Juvenile Offenders. In Proceeding of International Conference on Engineering, Technology, and Social Sciences (ICONETOS) (Vol. 1, No. 1, pp. 25-28). Google Scholar

Nukman. (2019, 22 June). The Result Interview, Teacher at Al-Azhar Air Tawar Padang, at Padang City. 
Nurjan, S., Tjahjono, H. K., \& Yamin, M. N. (2019). Comparative Study on Adolescent Behavior Delinquency at the Institute of Islamic Education Ponorogo. Google Scholar

O'Dwyer, L. M., \& Bernauer, J. A. (2013). Quantitative Research for the Qualitative Researcher. SAGE Publications. Google Schoolar.

Pratiwi. (2019, 12 June). The Result Interview, Student at SMAN 3 Padang, at Padang City.

Rifqi, A. (2014). Sistem Pembelajaran Pendidikan Agama Islam pada Perguruan Tinggi Umum. Yogyakarta: Deepublsh. Google Scholar

Syafe'i, I. (2017). Pondok pesantren: Lembaga pendidikan pembentukan karakter. Al-Tadzkiyyah: Jurnal Pendidikan Islam, 8(1), 61-82. https://doi.org/10.24042/atjpi.v8i1.2097.

Tolib, A. (2015). Pendidikan di pondok pesantren modern. Risâlah, Jurnal Pendidikan Dan Studi Islam, 2(1), 60-66. https://doi.org/10.31943/jurnal_risalah.v2i1.12.

Yerni. (2019, 25 June). The Result Interview, Teacher at SMAN 3 Padang, at Padang City.

Zamani, D. A., \& Al Baqi, S. (2019). The Effectiveness of Islamic Guidance and Counseling to Reduce the Tendency of Juvenile Delinquency. At-Ta'dib, 14(1), 1-19. http://dx.doi.org/10.21111/at-tadib.v14i1.3391

Zuriyani, E., \& Despica, R. (2020). The study of crime and its relation to the development. Masyarakat, Kebudayaan dan Politik, 33(1), 47-57. Google Scholar

Copyright Holder :

(c) Zaini, H., Andi, N., \& Putri, H. (2020).

First Publication Right :

(C) Jurnal Iqra' : Kajian Ilmu Pendidikan

This article is under:

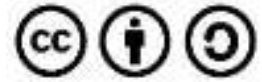

